\title{
ATUAÇÁO DOCENTE NO MODELO DE EDUCAÇÁO A DISTÂNCIA (EAD): UMA APRECIAÇÃO CRÍTICA SOBRE O PAPEL DOS TUTORES NO ENSINO SUPERIOR
}

\author{
TEACHING PERFORMANCE IN THE DISTANCE EDUCATION MODEL \\ (E-LEARNING): A CRITICAL APPRAISAL ABOUT THE ROLE OF TUTORS \\ IN COLLEGE
}

\author{
Flavia Alves de Jesus Ferreira ${ }^{\mathrm{I}}$ \\ Ana Elizabeth Lapa Wanderley Cavalcanti ${ }^{\text {II }}$ \\ Irineu Francisco Barreto Junior ${ }^{\mathrm{III}}$
}

\footnotetext{
I Faculdade Diadema, São Paulo, SP, Brasil. Mestre em Direito. E-mail: flaviajesusadvocacia@globo.com
}

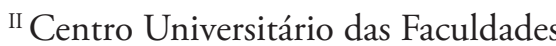
Metropolitanas Unidas, São Paulo, SP, Brasil. Doutora em Direito. E-mail: aelwc@terra.com.br

III Centro Universitário das Faculdades Metropolitanas Unidas, São Paulo, SP, Brasil. Doutor em Ciências Sociais. E-mail: neubarreto@hotmail.comr

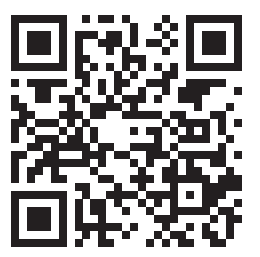

DOI: http://dx.doi.org/10.31512/rdj.v21i40.406
Resumo: O presente artigo analisa o papel dos tutores, profissionais responsáveis pela interação entre discentes no ambiente virtual de aprendizagem. Oferece visão crítica a respeito da posição dos tutores no ensino a distância $(\mathrm{EaD})$. Para tanto, entende-se necessário o estudo do papel deste profissional essencial para o êxito do estudo a distância, modalidade de aprendizagem que conta com particularidades desafiadoras e que também impóe o desenvolvimento de habilidades compatíveis com o ambiente, tais como conhecimento técnico para o uso da informática, novos modelos de comunicação oral e escrita e desenvolvimento de atitudes mais flexíveis que atendam ao relacionamento não presencial entre o discente e o profissional. A metodologia do artigo fundamenta-se na técnica analítica e dedutiva, na qual são avaliados aspectos da evolução da educação superior brasileira na Sociedade da Informação, adotando o referencial epistemológico formulado por Manuel Castells e o ordenamento jurídico brasileiro pertinente ao tema. A pesquisa conclui que a tecnologia, colocada a serviço da educação, tem o poder de promover a efetivaçáo do dispositivo constitucional garantidor do direito de acesso à educaçâo integral e universal, contudo, isto não acontece espontaneamente, se faz necessária a implementação de metodologias educacionais inovadoras e capacitação de docentes e tutores, imprescindíveis ao êxito do processo educacional.

Palavras-chave: Sociedade da Informação; Ensino a Distância; Educaçâo Superior; Metodologias Educacionais.

Recebido em: 20.09.2019

Aceito em: 09.03.2021 


\begin{abstract}
This scientific paper analyzes the tutors's role, professionals responsible for the interaction between students in the virtual learning environment. Offers a critical view about the position of so-called tutors in distance learning. It is necessary to study the role of the professor-tutor as an essential professional for the success of distance learning, a modality that has challenging particularities and that also requires the teacher to develop skills compatible with the environment, such as technical knowledge for the use of computers, new oral communication and writing models and the development of more flexible attitudes that assists the non-presential relationship between the student and the professional. The methodology of this article is based on the analytical and deductive technique, in which aspects of the evolution of Brazilian higher education in the Information Society are evaluated, adopting the epistemological referential formulated by Manuel Castells and the Brazilian legal order relevant to the theme. The research concludes that technology, placed at the service of education, has the power to promote the effectiveness of the constitutional provision guaranteeing the right of access to integral and universal education, however, this does not happen spontaneously, it is necessary to implement innovative educational methodologies and training of teachers and tutors, essential to the educational process's sucess.
\end{abstract}

Keywords: Information Society; E-learning; Higher Education; Education Methodologies.

\title{
1 Introdução
}

A educação superior brasileira atravessou uma série de transformaçóes significativas nas últimas décadas, que alteraram substancialmente as instituiçôes de ensino, cursos, e provocaram mudanças inéditas no perfil dos ingressantes e concluintes. Com fundamento no marco legal estabelecido na Constituição Federal de 1988 e Lei de Diretrizes e Bases da Educação (LDB) ${ }^{1}$, uma série de política públicas, preconizadas pelo Conselho Nacional de Educação, propiciaram a expansão do aparelho formador do ensino superior e o ingresso de segmentos populacionais até então pouco presentes nos cursos universitários. No rol destas políticas estão o estímulo à abertura de novas instituiçôes de ensino (IES), expansão da autorização para funcionamento de cursos e abertura de novas vagas no governo Fernando Henrique Cardoso, políticas estas continuadas a ampliadas no governo Lula, com a criação do Programa Universidade Para Todos (ProUNI), do Programa de Financiamento Estudantil (FIES) e da expansão do parque das universidades públicas federais.

Esse conjunto de políticas propiciou a ampliação do número de instituiçóes de ensino superior públicas e privadas. No caso das primeiras, o aumento se deveu às políticas

1 Lei n. ${ }^{\circ} 9.394$ de 20 de dezembro de 1996. 
de financiamento (FIES) e inclusão social (ProUNI), enquanto o crescimento da rede federal derivou de políticas consideradas estratégicas pelos sucessivos mandatários do Executivo Federal.

Concomitantemente às políticas públicas inclusivas, a educação superior brasileira presenciou a inédita incorporação do aporte tecnológico propiciado pela Internet na expansão do ensino a distância. $\mathrm{O} \mathrm{EaD}$ antecede a Internet e constitui uma tradicional técnica de aprendizagem, no Brasil e no mundo, voltada ao ensino pratico, capacitação e aprimoramento de profissionais impedidos de frequentar o ensino presencial ou que preferem aprender a distância. O ensino a distância apresenta particularidades em relação ao presencial, que envolvem desde o desenho dos cursos, metodologias de ensino e avaliação, cumprimento de requisitos como estágio supervisionado e trabalho de curso, assim como a redação de planos de ensino adequados às particularidades do $\mathrm{EaD}$ e, por fim, a formação de professores e tutores aptos a exercer suas competências no meio digital.

O impulsionamento do EaD ocorreu majoritariamente em instituição de ensino privadas e o cursos com maior aporte de alunos foram as licenciaturas (Pedagogia e curso de formação docente) e os tecnológicos (áreas de tecnologia da informação e formação tecnológica). ${ }^{2}$

Este artigo analisa de forma crítica o papel dos tutores no ensino a distância, profissional responsável pela interação dos discentes no denominado ambiente virtual de aprendizagem, saneamento de dúvidas, promoção de debates/interlocução entre discentes e até mesmo realização das avaliaçôes e retorno com feedback no processo formativo. Considera que a atuação dos tutores é imprescindível para êxito do ensino a distância e que essa modalidade conta com particularidades desafiadoras, tais como as condiçóes dos alunos para angariar habilidades e competências determinadas nos parâmetros curriculares do seu curso e que exigem, no EaD, organização do tempo, habitualidade com leitura científica, autonomia para o aprendizado amparada em interação episódica com o tutor e concentração perante os recursos de aprendizagem virtual.

Dessa forma, o artigo considera que o $\mathrm{EaD}$ não é uma modalidade concorrente do ensino presencial e sim uma técnica distinta, que exige habilidades outras dos estudantes - se comparados aos alunos típicos da modalidade presencial. $\mathrm{O}$ mais recente Censo da Associaçáo Brasileira de Educação a Distância $(\mathrm{ABED})^{3}$, publicado em 2018, revela que 77,8\% dos alunos nessa modalidade têm entre 26 e 40 anos e apenas 3,9\% estão abaixo dos 20 . Mais idade pode representar disciplina mais efetiva para os estudos, advinda da maturidade, porém pode ser desafiadora quando representar um hiato muito largo entre o término do ensino médio e o início da formação superior, que pode provocar a perda da habitualidade com os estudos sistematizados e avaliação dos discentes.

2 MINISTÉRIO DA EDUCAÇĀO; INEP. Censo da Educação Superior 2019. Brasília-DF: INEP, 2020.

3 ABED. Censo da Associação Brasileira de Educaçáo a Distância. Disponível em: http://www.abed.org.br/ site/pt/midiateca/censo_ead/. Acesso em: 29 jul. 2019. 
Quase dois terços dos alunos do $\mathrm{EaD}(63,5 \%)$ são originários de escolas públicas de ensino médio e parcela ainda mais significativa $(64,6 \%)$ é concentrada nos segmentos de renda familiar D (entre dois e quatro salários mínimos) ou E (até dois salários mínimos). Se representa uma possibilidade de inclusão de camadas sociais ao ensino superior, esse quadro também é revelador de desafios pois as notas do Enem mostram que alunos de escolas particulares e dos estratos superiores de renda, estatisticamente, apresentam melhor performance nessa avaliação.

Outro desafio colocado para o $\mathrm{EaD}$ é a decisão dos conselhos federais de Farmácia, Medicina Veterinária e Arquitetura por barrar o registro de egressos de profissionais formados nessa modalidade formativa ${ }^{4}$. Os Conselhos alegam que as atividades práticas propostas nos cursos online são insuficientes para a adequação da formação e há inúmeras restriçóes para a realização do estágio supervisionado nas graduaçôes a distância. Há um embate jurídico nessa decisão uma vez que os conselhos não possuem competência para chancelar a validade de um curso e a legislação brasileira não diferencia as modalidades presenciais e $\mathrm{EaD}$. Os conselhos alegam não estar interferindo nos critérios de formação, competência exclusiva do Ministério da Educação, e sim exercendo seu papel de regular o exercício da profissão. ${ }^{5}$

A metodologia da pesquisa adota o referencial epistemológico formulado por Manuel Castells, voltado a analisar o estágio atual de desenvolvimento social e econômico denominado Sociedade da Informação, no qual a informação adquire o status de mercadoria e vê multiplicada sua potencialidade de gerar valor. Conforme este autor (2001, p.22), o transcorrer do Século XXI tem assistido a um novo estágio do desenvolvimento histórico, econômico, cultural, social, e político, cujo marco iniciai é uma ruptura dos padróes de sociabilidade provocada por uma série de eventos sistêmicos e concatenados em escala mundial, aos quais se convencionou denominar como Sociedade da Informação. A educação, assim como os demais segmentos sociais, é submetida a reflexos da Sociedade da Informação e sua modalidade a distância é a evidência que mais bem corrobora essa assertiva. Em termos da técnica de pesquisa, o artigo adota o enfoque dedutivo com o intuito de compreender as abordagens teóricas sobre o papel do tutor no ensino a distância e os desafios impostos pelo ambiente virtual de aprendizagem para a efetivação dos objetivos didático-pedagógicos do ensino superior.

\section{Composiçáo Docente no EaD e sua implementaçáo no ensino superior}

$\mathrm{O}$ artigo contextualiza o Ensino a Distância no ambiente informacional cujo desenvolvimento recente, a partir da década de 1990, inaugurou o ciclo histórico denominado na literatura como Sociedade da Informação. Essa nova era resulta dos avanços na interconectividade planetária, inaugurados com a globalização econômica, cujos desdobramentos resultam na dissolução das fronteiras entre, de um lado, telecomunicação, meios de comunicação de massa,

4 Jornal Folha de S. Paulo. Conselhos barram registro de formados online. Suplemento Especial Educaçáo a Distância. 28 de julho de 2019, p.4.

5 Ibid, p.4. 
tecnologias de comunicação e informação e, por outro, as relaçôes sociais, políticas, movimentos culturais e a ampla gama de inter-relacionamentos humanos mediados pela internet.

Convencionou-se nomear esse novo ciclo histórico, segundo Barreto Junior (2007, 49) como Sociedade da Informaçâo, cuja principal marca é o surgimento de complexas redes profissionais e tecnológicas voltadas à produçâo e ao uso da informaçấo, que alcançam ainda sua distribuiçáo através do mercado, bem como as formas de utilizaçáo desse bem para gerar conhecimento e riqueza.

Não é possível admitir que essas mudanças sejam atomizadas, na realidade a Sociedade da Informação inaugura um novo estágio de desenvolvimento do Capitalismo no qual as sociedades contemporâneas atravessam uma verdadeira revolução digital. Nela, são dissolvidas as fronteiras entre telecomunicaçóes, meios de comunicação de massa e informática

$\mathrm{Na}$ Sociedade da informação o conhecimento nasce da transformação de registros informáticos em conhecimento. Neste contexto, a docência pode ser compreendida como ação educativa que se constitui no processo de ensino-aprendizagem, pesquisa, gestáo de contextos educativos e na perspectiva da gestão democrática. Na visão de Masetto (2008), docência no ensino superior implica em: domínio de conhecimentos específicos em uma determinada área a serem mediados por um professor para os seus alunos, conceito este que é complementando por Freire (1996, p. 22-23) ao afirmar quem ensina aprende ao ensinar e quem aprende ensina ao aprender.

O Ensino a Distância é impulsionado no contexto da Sociedade de Informação. Sem a interconectividade mundial e as inovações nas tecnologias de comunicação e informação o ensino on-line náo teria atingido os patamares como ora vistos no contexto da Pandemia da Covid -19, no qual o ensino presencial foi forçado a migrar para o on-line em questão de semanas. E o ensino remoto apresenta uma série de diferenças em relação ao presencial. No caso da atuação dos docentes e dos tutores, no $\mathrm{EaD}$ a tutoria se desenvolve como uma funçáo inerente a de um professor, entretanto, observa-se que a IES que pretenda atuar nesta área, ao compor seu corpo docente deve observar certas habilidades de que deve ser dotado este tutor.

Na visão de Guarezi e Matos (2009), os professores-tutores devem ser avaliados na sua competência em três aspectos. Primeiramente os conhecimentos pertinentes ao conteúdo do curso; depois as habilidades: a. uso de tecnologias de informática; b. comunicação oral e escrita; e por fim atitudes, que implicam na flexibilidade, na facilidade no relacionamento interpessoal e na postura ética.

$\mathrm{Na}$ modalidade ensino a distância o docente (tutor) é mediador, atuando na interface entre sistema (plataforma) e estudante. Assim, na capacitação para realizar a mediação pedagógica, ele deve demonstrar experiência com as tecnologias de informática, afim de aplicar as ferramentas correspondentes (fórum, wiki, chat, vídeo aulas, entre outros) de acordo com os conteúdos apresentados. $\mathrm{O}$ ambiente virtual de aprendizagem náo pode pressupor dos requisitos fundantes do processo educacional, dentre as quais a premissa de que é necessária a 
presença do professor/mediador de atividades, que permite ao aluno interagir de modo que as relaçôes interpessoais sejam apreciadas. $\mathrm{O}$ artigo considera importante fazer esta abordagem com o intuito de promover comparaçóes que permitam diferenciar as práticas docentes presenciais daquelas realizadas em EaD, sobretudo no papel de cada ator. Nesse sentido, Sá (1998, p.47) defende que a prática educacional a distância:

É acompanhada pelo tutor; atendimento ao aluno, em consultas individualizadas ou em grupo, em situaçóes em que o tutor mais ouve do que fala; processo centrado no aluno; diversificadas fontes de informaçóes (material impresso e multimeios); interatividade entre o aluno e tutor, sob outras formas, não descartada a ocasião para momentos presenciais; ritmo determinado pelo aluno dentro de seus próprios parâmetros; múltiplas formas de contato, incluída a ocasional face a face; avaliação de acordo com parâmetros definidos, em comum acordo, pelo tutor e pelo aluno; atendimento pelo tutor, com flexíveis horários, lugares distintos e meios diversos.

Pereira (2007, p. 86) aponta aspectos necessários à organização e ao desenvolvimento do trabalho de tutoria, pois na organização e no trabalho desta é necessário refletir sobre a importância dos seguintes aspectos sobre o ambiente de ensino e aprendizagem:

$\mathrm{O}$ ambiente de ensino e aprendizagem proposto define o campo de atuação, a modalidade de tutoria a ser adotada e a natureza de sua atuação. Quanto ao campo de atuação, haveria: tutoria de conteúdo, a tutoria de aprendizagem e a tutoria de apoio, de acordo com cada proposta de ensino e aprendizagem. Quanto às modalidades de tutoria, existem as possibilidades de tutoria presencial, postal, telefônica ou online, indicando que a modalidade permanece vinculada ao meio de comunicação utilizado para os contatos com os alunos. Além disso, as tecnologias da informação utilizadas consistem em tecnologias educativas, mediaçôes tecnológicas que determinarão o desenvolvimento de competências de conteúdo, tecnologias e colaborativas.

Para uma compreensão mais acurada do objeto abordado neste estudo é necessário conhecer as definiçóes e origens históricas acerca do tutor e da tutoria. A origem etimológica da palavra latina tutor significa "protetor, defensor, pessoa legalmente encarregada de tutelar alguém” (CUNHA, 1986, p. 799). Isso nos leva a concluir, erroneamente, que há nesta palavra a indicação de desigualdade entre partes, de não-reciprocidade, superioridade de comando. Juridicamente, tutor é a aquela pessoa civilmente capaz, a quem a lei incumbe o cuidado de outra pessoa que, por sua vez, não tenha alcançado a maioridade civil, carecendo de representantes legais. Trata-se do responsável jurídico pelo menor, administrando-lhe seus bens, seu patrimônio e sua educação.

Com base na visão do autor supracitado, a tutoria é uma atividade inerente à função do professor, realizada individual e coletivamente com alunos em sala de aula ou fora dela, facilitando a integração pessoal nos processos de aprendizagem; é a ação de ajuda ou orientação ao aluno que o professor pode realizar além de sua própria açâo docente e paralelamente a ela. Nesse sentido, compreende-se tutor e tutoria como dois conceitos complementares que significam o conjunto das atuaçóes de orientação pessoal, acadêmica e profissional formulado pelos professores com a colaboração dos alunos e da própria instituição. Baraúna, Arruda e 
Arruda (2012, p. 284) apontam para alguns equívocos na associação reducionista entre ensino a distância e computador.

É interessante notar que há alguns equívocos do senso comum que vinculam a $\mathrm{EaD}$ a tecnologias contemporâneas como o computador. Ocorre que as tecnologias baseadas na microinformática acabam por tornar a $\mathrm{EaD}$ mais "atrativa", principalmente devido a uma característica exclusiva: a possibilidade de produção e transmissão de conteúdos por qualquer pessoa, diferentemente do rádio e da televisão, cuja produção era e continua sendo, necessariamente, elaborada por uma equipe produtora e transmitida com baixas taxas de interação com o ouvinte ou telespectador.

Com o advento da internet, em resposta à evolução tecnológica, softwares foram desenvolvidos, permitindo e facilitando a interação entre as pessoas na forma de entretenimentos, notícias, e outros focados no sistema de ensino e aprendizagem, sendo estes denominados Ambientes Virtuais de Aprendizagem (AVA). Em relaçóes a essas tecnologias discussóes pedagógicas se desenvolveram apontando a necessidade de novas metodologias educacionais, como meio de apoio ao aprendizado à distância.

Concomitantemente, os educadores passaram a utilizar softwares para facilitar a aprendizagem, dentre eles: TelEduc, Moodle, Solar, Sócrates, etc. Estes programas inegavelmente oferecem algumas vantagens, tais como facilitar a interação entre aluno e dispositivo informático; autonomia do aluno quanto ao ritmo de aprendizagem; facilitar a interação entre aluno e docente e derrubada de barreiras geográficas que impediam o acesso aos moradores afastados dos grandes centros urbanos.

Autores como Thompson (1998) e Peters (2004) apontam para duas abordagens pedagógicas utilizadas no ambiente virtual: a instrumental e a conectiva. $\mathrm{Na}$ abordagem instrumental o aluno, sem a mediação pedagógica de um profissional de $\mathrm{EaD}$, aborda teores educativos a partir de um foco de transmissão de conteúdo, o que em tese seria uma "Educação Bancária" na visão de Paulo Freire (1996), onde a relação entre receptor e emissor é de natureza vertical, sendo o emissor o detentor do conhecimento e quem determina, enquanto que o receptor é aquele que recebe o conhecimento de forma passiva, sem a oportunidade de problematizar ou mesmo questionar as situaçôes abordadas através do conteúdo apresentado no curso.

Já na abordagem conectiva, seu ponto de apoio está na comunicação como mediadora no processo de ensino e aprendizagem, ocorrendo a interação e o diálogo entre o professor-tutor e o aluno, bem como entre os próprios alunos, aspectos estes que são considerados fundamentais para o processo educativo, num processo de construção coletiva de aprendizagem, pois são estes momentos de interação, que são permeados de questionamentos, problematizaçóes, discussôes e dúvidas que oportunizam a reflexão, a transformação e a construção de novos conhecimentos.

Também denominados professores tutores, são eles responsáveis por redefinirem novas atividades de preparação, de elaboração de materiais, de produção ou de trocas de conhecimentos, de formas de comunicação mediatizadas pelos instrumentos tecnológicos, exigindo, deste, novas 
competências, atitudes e atividades cognitivas para exercerem estas novas funçóes e papéis, ou seja, observamos que o professor-tutor é o responsável por todas as etapas dos cursos, desde o planejamento, a produção de materiais, o acompanhamento e avaliaçáo do processo de aprendizagem dos alunos.

De acordo com a visão de Preti (2000), as Tecnologias da Informação e Comunicação (TICs) no EaD são meios e não fins em si mesmas, isto por serem as mesmas carregadas de valores, conceitos, visóes de sociedade, processos de conflitos e privilégios, etc., não são neutras. Elas implicam na questão pedagógica da apropriação das tecnologias pela educação presencial ou a distância, o que significa conhecer a dimensão comunicacional da educação que se estabelece no discurso do texto, na imagem, no som, nos processos cognitivos e nas relaçóes interpessoais, como defende Lobo Neto (2000).

Os resultados de aprendizagem nos discentes que participam dos cursos em que apenas ocorram a ação de transmissão de informaçôes serão muito mais incipientes no que se refere à construção do conhecimento, se comparados àqueles que participam de formação realizada por meio da mediação do professor-tutor/ aluno, indicando o papel positivo da mediaçáo, diante da necessidade de interação entre o aluno e o educador e entre estes e os demais estudantes do curso.

O docente-tutor deve apoiar e motivar o aluno levando-o à reflexão, questionamento e levantamento de hipóteses sobre seu processo de aprendizagem e realizando o acompanhamento de todo seu progresso no processo de construção e compartilhamento do conhecimento. Dessa forma, o tutor é um mediador pedagógico do processo de ensino e aprendizagem, que assume conjuntamente à docência e deve ter plenas condiçóes de mediar conteúdos e intervir na mensagem para promover a aprendizagem, entretanto, ainda carece de regulamentação.

Há uma tendência, a ser superada, de que os professores de cursos $\mathrm{EaD}$ desenvolvam suas atividades como se estivessem em um ambiente presencial, sem considerar as especificidades do ambiente virtual. Do ponto de vista das ferramentas, podem se destacar dois tipos: as síncronas, pelas quais os participantes se conectam no ambiente simultaneamente; e as assíncronas, pelas quais os usuários interagem no sistema em momentos diferentes, por exemplo, os chats, as vídeoaulas, fórum, lista de discussão, wiki, diário de bordo e outros.

Apesar dos inúmeros recursos, o professor-tutor comumente ainda fica limitado à solicitação de atividades relacionadas à produção de textos. Para atuar neste cenário, o tutor virtual deve possuir certas habilidades como, por exemplo, saber administrar bem o seu tempo, pois ao contrário do professor de cursos presenciais, o professor - tutor náo tem certeza se o aluno fará novas interaçôes. Para evitar que os alunos tenham uma compreensão errônea dos conteúdos abordados, suas intervençôes devem ser específicas. A criação da sala de aula na modalidade EAD é mais complexa, pois o professor tutor precisa aprender a associar as atividades a distância ao material impresso. Sobre essa questão Cortelazzo (2015) afirma:

[...] se os professores conhecerem a tecnologia que usa esses meios como suporte e praticar a leitura e, até mesmo, a escrita dessas mídias eletrônicas para poderem trabalhar, com 
seus alunos, "o conhecimento caoticamente retido através dos meios de comunicação de massa e das mais diversas tecnologias", poderão incentivá-los a produzir novos conhecimentos dando a sua contribuição para o conhecimento coletivo.

A educação concebida para este modelo é aquela na qual uma ação consciente e participativa possibilita ao aluno a construção de um projeto profissional político e inovador, é assim que cada pessoa conectada à internet se transforma em um ponto receptor e transmissor de informaçôes de forma livre, a um baixo custo e com potencial de grande abrangência. Neste caso, é forçoso admitir que a figura do professor deixou de ser o único detentor do conhecimento, porém sua atuação é imprescindível e necessária, e é nesta perspectiva que se situa a ação tutorial, propiciando ao estudante a distância um ambiente de aprendizagem personalizado, capaz de satisfazer suas necessidades educativas, isto porque o aluno da modalidade EaD deixa de ser mero espectador para se tornar produtor de informação que gera conhecimento.

Releva-se a importância do tutor como mediador, cabendo ao "professor tutor" papel relevante de intérprete do curso junto ao aluno, esclarecendo suas dúvidas, o estimulando a prosseguir e, ao mesmo tempo, participando da avaliação da aprendizagem.

\section{Diferenças significativas entre docentes e tutores}

$\mathrm{Na}$ formação de um professor tem-se como um dos primeiros passos a tomada de consciência quanto às funçôes docentes, divididas por Belloni (1999, p. 115 em três grandes grupos, a saber:

O primeiro é responsável pela concepção e a realização do curso e materiais; o segundo assegura o planejamento e organização da distribuição de materiais e da administração acadêmica (matrícula e avaliação); e o terceiro responsabiliza-se pelo acompanhamento do estudante durante o processo de aprendizagem (tutoria, aconselhamento e avaliação).

Para Vigneron (1997, p. 218), o docente deverá estar preparado para as inovaçóes tecnológicas e as consequências pedagógicas destas. $\mathrm{O}$ autor pondera ainda que muitos professores não receberam formação para estas novas tecnologias da informação e comunicação. Ressalta-se, assim, a necessidade da existência de investimentos das universidades na formação permanente, e que conteúdos correspondentes também integrem a capacitação da docência em $\mathrm{EaD}$. As aulas presenciais e o excesso de alunos em uma sala de aula não são os maiores desafios, pois isto se tornou uma realidade à qual os professores já estão acostumados, seja no ensino público ou privado. Porém, atender um excessivo número de alunos por via eletrônica, tornou-se uma das tarefas do tutor, sendo necessário maior investimento em uma formaçáo especializada deste, conforme Neder (2000, p. 30):

[...] torna-se imprescindível que o orientador acadêmico tenha uma formação especial, em termos dos aspectos político-pedagógicos da Educação a Distância e da proposta teórico-metodológica do curso que ajudará a construir. 
Segundo Sá (1998, p. 47), existem diferenças de funçóes do professor convencional e do que seria a função ideal do tutor em ambientes virtuais de aprendizagem do $\mathrm{EaD}$. A educação presencial, segundo a autora, está caracterizada da seguinte forma:

É conduzida pelo professor; predomínio de exposiçóes o tempo inteiro; o processo é centrado no professor; processo como fonte central de informação; convivência em um mesmo ambiente físico, de professores e alunos, o tempo inteiro; ritmo de processo ditado pelo professor; contato face a face entre professor aluno; elaboraçâo, controle e correção das avaliaçôes pelo professor; atendimento pelo professor, nos rígidos horários de orientação e sala de aula.

De acordo com o entendimento de Mattar (2012), supóe-se que o tutor tenha ocupado posição inferior na hierarquia docente na Educação a Distância, isto por conceber-se um aluno com autonomia suficiente para estudar sozinho, bastando um bom conteúdo e um monitor que lhe atenda mais como um suporte do que um mediador. Essa postura, porém, difere do que propóem Bruno e Lemgruber (2009), que defendem a mudança da nomenclatura professortutor. Estes autores consideram que o tutor a distância é um docente e não mero estimulador ou monitor de suporte técnico, e muito menos um repassador de pacotes instrucionais.

A ligação aluno-professor ainda é, no imaginário pedagógico, uma dominante, o que torna a tutoria um ponto - chave em um sistema de Educaçáo a Distância, discorre Maia (2002) ao citar Niskier. A palavra professor procede da palavra "professore", que significa "aquele que ensina ou professa um saber" Alves e Nova (2003). Era comum sustentar, na perspectiva tradicional da Educação a Distância, a ideia de que o tutor dirigia, orientava, apoiava a aprendizagem dos alunos, mas não ensinava.

$\mathrm{Na}$ verdade, sustentava-se a ideia de que eram os materiais que ensinavam e o lugar do tutor passou a ser o de um acompanhante funcional para o sistema. Litwin (2001) discorre sobre algumas consideraçôes importantes sobre esta relação entre o ensino e o professor - tutor. Para ele, o lugar do ensino, assim definido, ficava a cargo dos materiais, "pacotes" autossuficientes, sequenciados e pautados, que finalizavam com uma avaliação semelhante em sua concepção de ensino.

Assim se pensava quando ensinar era sinônimo de transmitir informações, ou de estimular o aparecimento de determinadas condutas. Nesse contexto, a tarefa do tutor consistia em assegurar o cumprimento dos objetivos, servindo de apoio ao programa. Na visão do autor (Idem), quem é um bom docente será também um bom tutor. Um bom docente "cria propostas de atividades para a reflexão, apoia sua resolução, sugere fontes de informação alternativas, oferece explicaçóes, facilita os processos de compreensão; isto é, guia, orienta, apoia, e nisso consiste o seu ensino".

Da mesma forma, o tutor deve promover a realização de atividades e apoiar sua resoluçáo, e não apenas mostrar a resposta correta; oferecer novas fontes de informação e favorecer sua compreensão. "Guiar, orientar, apoiar" são verbos devem referir à promoção de uma compreensão 
aprofundada e o desenvolvimento destas habilidades são de responsabilidade tanto do docente, no ambiente presencial, como do tutor na modalidade a distância.

Conforme se verifica, as habilidades básicas necessárias ao tutor não são antagônicas àqueles esperadas de um docente presencial. Por sua vez, ele deve compreender a estrutura do assunto ao qual se refere nas aulas, os princípios da sua organização conceitual e os princípios das novas ideias produtoras de conhecimento na área. Sua formação teórica sobre aspectos pedagógicos e didáticos deverá ser atualizada com a formação na prática dos ambientes tutoriais.

A tecnologia está no âmago do $\mathrm{EaD}$ o que exige interação entre professores e alunos, diferindo em sua organização e desenvolvimento quanto ao formato presencial. Segundo Alves (2003), para a veiculação do ensino nessa modalidade, se faz necessária uma infraestrutura organizacional complexa (técnica, pedagógica e administrativa), com pressuposto na formação de equipes que trabalharão no desenvolvimento de cada curso e no desenho da pedagogia online. Segundo Sá (1998), a atual tendência de caracterização dos professores de ambientes de EaD é a de reprodutora do docente tradicional ou como um suposto tutor, cuja função se limita a auxiliar na aprendizagem, sem nenhuma identidade específica.

Os professores nos ambientes de $\mathrm{EaD}$ tendem a reproduzir suas práticas como se estivessem em uma sala de aula convencional, esquecendo das peculiaridades desses ambientes. Tonnetti (2012, p.7) tece consideraçóes sobre a atuação do tutor e o trabalho docente na educação a distância:

Estamos diante de uma forma bem diferente de educação, há na relação entre professor e aluno os artefatos, ou seja, as tecnologias pensadas para essa modalidade de educaçáo. "Não há uma interação direta entre professores e alunos porque há artefatos entre eles. Não têm que lidar com pessoas, mas sim com máquinas". Sem dúvidas o capitalismo confere diferentes formas de trabalho docente, consequentemente novas relaçóes pedagógicas - mediaçóes - e novas formas de ensinar. Diante desse cenário, o trabalho do professor é determinado e controlado pelas tecnologias de mediação.

Tem-se que o papel do docente não é somente passar conteúdo, mas orientar a construção do conhecimento pelo aluno, funcionando como um agente organizador, dinamizador até da sua autoaprendizagem, potencializando e sua responsabilidade social: "Seu lugar de saber seria o do saber humano e não o do saber informaçóes" (ALVES, 2003). Referidas funçóes, para serem exercidas competentemente, necessitam de formação especializada. Assim, atualmente a noção da formação permanente vigora para todas as profissôes, em especial na área da educação.

$\mathrm{O}$ adequado desempenho desses profissionais repousa sobre a crença de que apenas ensina quem aprende. Este é o alicerce do construtivismo pedagógico, conforme Grossi \& Bordin (1992). São pressupostos na formação acadêmica a capacidade intelectual e domínio dos conteúdos, destacando-se as técnicas metodológicas ativas e didáticas inovadoras. Deve-se conhecer com profundidade os assuntos relacionados com a matéria e área profissional em foco, além de planejar, acompanhar e avaliar atividades, bem como motivar o aluno para o estudo, sendo estas as habilidades relevantes. 
$\mathrm{Na}$ formação pessoal, deve ser capaz de lidar com o heterogêneo quadro de alunos e ser possuidor de atributos psicológicos e éticos: maturidade emocional, empatia com os alunos, habilidade de mediar questôes, liderança, cordialidade e, especialmente, a capacidade de ouvir. Segundo Takahashi (2000), para que o Ensino a Distância alcance o potencial de vantagem que pode oferecer, é preciso investir no aperfeiçoamento do professor e do tutor e, sobretudo, regulamentar a atividade de tutor, além de definir e acompanhar indicadores de qualidade.

\section{Aspectos controversos entre o papel do tutor e do docente tradicional}

Ao longo dos anos, as experiências realizadas em busca de um modelo ideal de EaD, compreendendo dentro da palavra ideal os seguintes elementos: realização da vontade expressa pelo ordenamento jurídico; proporcionar educação ao alcance de todos, considerando a distância entre escola e instituição física; baixo custo tanto para o educando quanto para a instituição que tenha observado nesta modalidade oportunidade de ampliação dos serviços oferecidos e consequentemente maximização dos ganhos, nas busca da realização destes fatores, polêmicas foram surgindo.

Adotando uma perspectiva crítica, Santos, Oliveira e Junqueira (2016, p.13) assinalam que a crescente oferta de cursos à distância tem propiciado que diversos profissionais, com domínio de diferentes áreas do conhecimento, assumam o papel de tutores. Contudo, na visão dos autores, esses profissionais não possuem a devida formação pedagógica para atuar na EAD e restringem suas práticas assumindo o papel de agentes motivadores de alunos. Mais secretariam tempo e tarefas do que atuam como pedagogos, oferecendo estímulo aos alunos para que desenvolvam leituras, discussóes, promovam grupos de estudos e de debates, trabalhos colaborativos. Não de forma articulada com a formação pedagógica e sim com lembretes quanto ao cumprirem de metas, entregas de trabalhos no tempo estabelecido e interagindo com o setor administrativo da instituição à qual pertencem (SANTOS; OLIVEIRA; JUNQUEIRA, 2016, p.13).

Segundo Carlini (2010), referidas polêmicas vão desde a separação geográfica e espacial entre os participantes dos processos de ensino e de aprendizagem à efetivação e avaliação da qualidade do ensino, ao tratamento dado ao seu efetivo docente e tutoria pelas IES de EaD.

A questão da distância intrínseca ao modelo e sua característica principal, explicitada pelo Decreto 5622/2005, pode ser mitigada com a utilização de recursos tecnológicos de forma adequada, que vão desde a linguagem até os recursos mais sofisticados, com os quais o docente, ao adquirir habilidades com a tecnologia ofertada, possa sentir-se seguro para desenvolver e criar situaçôes de aprendizagem seguras e fundamentadas teoricamente.

Professores ainda podem experimentar a separação temporal, ou seja, o estudo ocorrerá em situação onde professor/tutor não necessariamente estarão participando no simultaneamente do processo, permitindo ao aluno maior flexibilidade de horários para organizar seus estudos e 
tarefas, principalmente considerando a implementação da tecnologia $3 \mathrm{G}$ em 2008, que propiciou o envio de material multimídia por meio de celular.

Ainda segundo Carlini, dificilmente o professor do ensino presencial tem controle do uso de celulares pelo discente que por vezes busca informaçôes por seu intermédio. $\mathrm{Na}$ busca de solucionar tal polêmica, haja vista a seriedade e qualidade do material encontrado nas redes, este avanço pode ser aproveitado para dar ao discente a melhor opçáo nas suas próprias buscas por material de estudo, sem perder a noção de que, como destaca Nunes (apud Carlini, 2010), a Educação a Distância não é planejada para substituir a educação presencial convencional.

É de se notar que a relação entre a educação presencial e a Educação a Distância é a complementariedade. Insta reconhecer que a tutoria é parte fundamental no Ensino a Distância, configurando parte da equipe multidisciplinar que compóe os recursos humanos. O tutor compóe um quadro diferenciado participando ativamente na prática pedagógica, e para contribuir com o processo de ensino e aprendizagem, acompanhamento e avaliação do projeto pedagógico, desenvolve atividades presenciais e a distância, e para tanto, além da formação intelectual, o profissional deverá demonstrar possuir habilidades com as novas tecnologias de comunicação e domínio de conteúdo. Tomiazzi e Brito (2014, p.1035) consideram que as atribuiçóes do tutor seguem após a execução das atividades com os alunos e deve criar e proporcionar outras práticas de apoio, sugerir outros meios de informação do conteúdo proposto e facilitar a compreensão e o entendimento do discente. "O tutor será o mediador dos processos educativos, orientando, guiando, vibrando nos acertos, e motivando sempre que os alunos encontrarem dificuldades durante o percurso.” (TOMIAZZI E BRITO, 2014, p.1035)

Tal posicionamento retoma a polêmica do sentimento de distância existente entre professor e aluno, o que nos leva a sugestionar que tal problema poderia ser amenizado com a utilização de recursos tecnológicos bem aplicados. Observemos que a autora (Ibid), ao analisar os índices, ressalta que:

Taxa de evasão é um indicador importante de que o curso, por algum motivo, não está atendendo aos alunos: seja por que não se adaptam à modalidade ou por que não se identificaram com o curso, ou por que o curso não oferece a qualidade técnica e o conteúdo desejado, trata-se de um tema que precisa ser tratado com muito cuidado. Nas instituições públicas, altas taxas de evasão significam que o investimento público não está atingindo seus objetivos. Nas instituiçôes privadas, significa perda de receita imediata.

$\mathrm{E}$ ao refletir sobre a questão do investimento em $\mathrm{EaD}$ ser maior exatamente nos cursos em que as taxas de evasão são maiores, afirma a autora (Ibid): "Os índices, de fato, são maiores nos cursos regulamentados totalmente a distância, e nos cursos livres não corporativos, com maior incidência de taxas entre 11 e 25\% de evasão". Com tal afirmação, podemos compreender que as IES investem para reduzir esta evasão, direcionados da seguinte forma:

Qualitativamente, estes investimentos estão direcionados principalmente a produção de conteúdo, tecnologia e inovação e capacitação de pessoal nos cursos regulamentados totalmente a distância e em produção de conteúdo, criação de novos cursos e tecnologia 
e inovação nos cursos livres não corporativos. Os dados revelam que é muito provável que o combate às altas taxas de evasão seja um forte motivador de investimento e aprimoramento constante do EaD no Brasil. (Ibid).

Se a busca por lucro é real, tanto quanto os investimentos, concluímos que fatores como: falta de identificação ou adaptação à modalidade do curso, e que levam à evasão, não são tão relevantes quanto o fator qualidade do ensino ofertado. A dúvida que paira é justamente em saber o quanto as IES estão de fato dispostas a investir nesta qualidade do $\mathrm{EaD}$, direcionando tais investimentos na formação dos docentes e em especial ao tutor, seja pela busca de qualidade nos cursos, ou quanto ao reconhecimento da valiosa contribuição que é dada por estes profissionais, elevando o conceito da IES, resposta esta que buscaremos nos capítulos a seguir.

\section{Requisitos para o exercício da tutoria e da docência no EaD}

Editais de convocação para processos seletivos demonstram os requisitos observados e exigidos pelas IES de EaD atualmente, e é através desta análise que estabeleceremos o nosso estudo em comparação ao docente do ensino presencial. Considerando que a análise legal fora realizada em capítulo anterior, daremos especial atenção à visão institucional e suas práticas cotidianas que levam ao surgimento de uma regra de caráter não jurídico a ser observada pelo mercado. De acordo com Nóvoa (1999, p. 15):

Inicialmente, a função docente desenvolveu-se de forma subsidiária e não especializada, constituindo uma ocupaçáo secundária de religiosos leigos das mais diversas origens. A gênese da profissão de professor tem lugar no seio de algumas congregaçóes religiosas que se transformavam em verdadeiras congregações docentes. Ao longo dos séculos XVII e XVIII, os jesuítas e os oratorianos, por exemplo, foram progressivamente configurando um corpo de saberes e de técnicas e um conjunto de normas e valores específicos da profissão docente.

As primeiras preocupaçóes com o estabelecimento de regras e critérios para seleção e nomeação de professores, os quais passariam gradativamente a ser submetidos à regulação do Estado, se deram com as reformas educacionais do século XVIII. A partir do final do século é que se tornou uma exigência a licença ou autorização do Estado para atuar como professor, e assim, a profissão docente ganhou forte intervenção e controle por parte do Estado, com efetiva manutenção de praticamente o que já estava estabelecido à época. Nóvoa (1999, p. 18) afirma que:

O processo de estatização do ensino consiste, sobretudo, na substituição de um corpo de professores religiosos (ou sobre o controlo da Igreja) por um corpo de professores laicos (ou sob o controlo do Estado), sem que, no entanto, tenho havido mudanças significativas nas motivaçóes, nas normas e nos valores originais da profissão docente: $\mathrm{o}$ modelo do professor continua muito próximo ao modelo do padre.

A legitimação oficial da atividade profissional, assim como o reconhecimento profissional dos docentes, ocorreu através da emissão de licenças para atuaçáo como tal, mesmo antes da 
vinculação com processos formativos específicos para a tal. Segundo o autor (Idem), o título (licença) era mais consistente do que um diploma. A institucionalização da profissão se deu com a expansão das escolas no século XIX e o crescente controle do exercício da docência. Nóvoa (1999, p. 18), faz a seguinte exposição a respeito dessa questão:

Os professores utilizam sistematicamente dois argumentos em defesa das suas reivindicaçóes socioprofissionais: o caráter especializado da sua ação educativa e a realização de um trabalho da mais alta relevância social. O desenvolvimento das técnicas e dos instrumentos pedagógicos, bem como a necessidade de assegurar a reprodução das normas e dos valores próprios da profissão docente, estão na origem de uma institucionalização de uma formação específica especializada e longa.

No que se refere ao professor, a Lei de Diretrizes e Bases da Educação, Lei 9.394, de 20 de dezembro de 1996, indica nos artigos 62 e 66, os requisitos para a docência, no que tange a sua formação:

Art. 62. A formação de docentes para atuar na educação básica far-se-á em nível superior, em curso de licenciatura plena, admitida, como formação mínima para o exercício do magistério na educação infantil e nos cinco primeiros anos do ensino fundamental, a oferecida em nível médio, na modalidade normal. (Redação dada pela lei no 13.415 , de 2017)

\section{$[\ldots]$}

Art. 66. A preparação para o exercício do magistério superior far-se-á em nível de pósgraduação, prioritariamente em programas de mestrado e doutorado. Parágrafo único. O notório saber, reconhecido por universidade com curso de doutorado em área afim, poderá suprir a exigência de título acadêmico. (BRASIL, LDB, 1996).

É consensual que a educação é capaz de promover mudanças sociais, sendo certo que estas ocorrem quando o indivíduo transforma seu modo de pensar, alterando seu comportamento, projetando essa mudança para fora de si, com reflexo nos ambientes nos quais se encontra inserido, mas para isto todo ser humano depende de provocação. Recorde-se que a primeira Constituição brasileira, de 1824, garantia em seu art. VIII o direito à educação a todos os Brasileiros e, não obstante, desde o início da colonização do Brasil, a prática da educação já não se estendia a todos, tornando-se um privilégio da elite daquela época.

\section{Conclusão}

A tecnologia tornou algo comum e o aparato tecnológico tornou-se componente indissolúvel da realidade. Há de se considerar, no entanto, que o avanço tecnológico promove efeitos positivos, tanto quanto negativos, tal como é o caso do processo de automação em ambientes industriais nos quais ocorre a substituição de milhares de trabalhadores por robôs e inteligência artificial. A resposta a estas mutaçôes não deve ser a negação da tecnologia, o mais indicado é a adaptação humana ao avanço informático e este processo somente poderá decorrer 
da educação, direito fundamental de segunda geração, inserida nos direitos sociais, econômicos e culturais, encontrando seu fundamento de legitimidade na condição digna do ser humano.

A tecnologia, colocada a serviço da educação, tem o poder de promover a efetivação do dispositivo constitucional garantidor do direito de acesso à educação por todos, entretanto, isto não acontece espontaneamente, se faz necessária a implementação de metodologias educacionais inovadoras e capacitação de docentes e tutores, imprescindíveis ao êxito do processo educacional. Percebe-se que está em curso, no Brasil, um processo de acelerada expansão do ensino na modalidade a distância. E tal processo vem demonstrando ampla aceitação por parte de governos de países em desenvolvimento. Este crescimento da $\mathrm{EaD}$ no Brasil reflete uma lógica de expansão baseada na autorização de novos cursos e vagas, no qual as licenciaturas são seus maiores atrativos em virtude do histórico déficit de profissionais.

Entretanto, estas movimentaçóes e dinâmica não se operam única e exclusivamente em face da legislação, ou mesmo do crescimento do número de IES, observamos que em meio a este movimento de expansão, tecnológica e jurídica, adquire novo status a tradicional prática da tutoria que, apesar de a nomenclatura ser muito antiga, o ensino distância coloca novos desafios à atuação deste profissional. A pesquisa considera que a tutoria é uma atividade inerente à função do professor, realizando-se individual e coletivamente com os alunos em sala de aula, facilitando a integração pessoal nos processos de aprendiz; é a ação de ajuda ou orientação ao aluno que o professor pode realizar além de sua própria açáo docente e paralelamente a ela.

Ser um tutor, professor ou professor-tutor de ensino a distância, não se revela algo elementar, pois há sempre o risco de reprodução no ambiente virtual do comportamento docente em aulas presenciais, o que não é adequado para o modelo. $\mathrm{O}$ profissional de $\mathrm{EaD}$ deve desenvolver outras habilidades e adaptar-se a abordagens pedagógicas distintas. Conforme visto anteriormente, no ambiente virtual diferenciam-se as abordagens instrumental e conectiva, sendo que, na primeira, não ocorre a mediação pedagógica de um profissional de $\mathrm{EaD}$ e foco da transmissão de conteúdo é fundado na relação vertical, bancária, criticada por Paulo Freire.

Por outro lado na abordagem conectiva o fulcro da educação está na comunicação como mediadora no processo de ensino e aprendizagem, pressupondo interaçáo e diálogo entre o professor-tutor e aluno, bem como, entre os próprios alunos, aspectos estes que são considerados fundamentais para o processo educacional, num processo de construção coletiva de aprendizagem, momentos de interação permeados, idealmente, de questionamentos, problematizaçôes, discussôes, dúvidas que oportunizam reflexão, transformação e construção de novos conhecimentos.

O fato do tutor ser mediador não deve desqualificar esse profissional em detrimento do professor pois dele espera-se capacitação docente específica, abordagem pedagógica própria e desempenho de funçáo multidisciplinar, tendo em vista ser um facilitador que ajuda o estudante a compreender os objetivos do curso, além de observador que reflete constantemente junto ao aluno a sua possível trajetória acadêmica. 


\section{Referências}

ABED. Censo da Associação Brasileira de Educaçáo a Distância. Disponível em: http:// www.abed.org.br/site/pt/midiateca/censo_ead/. Acesso em: 29 jul. 2019.

ALVES, João Roberto Moreira. A história da EAD no Brasil. In: LITTO, Frederic M.; FORMIGA, Marcos (Orgs.). Educação a Distância: estado da arte. São Paulo: Pearson Education do Brasil, 2009.

ALVES, Lucinéia. Educação a Distância: conceitos e história no Brasil e no mundo. Associaçáo Brasileira de Educação a Distância. Disponível em: http://www.abed.org.br/ revistacientifica/Revista_PDF_Doc/2011/Artigo_07.pdf. Acesso em: 16 mai. 2018.

ALVES, Lynn; NOVA, Cristiane. Educação a Distância: Uma Nova Concepçáo de Aprendizagem e Interatividade. São Paulo: Futura, 2003.

BARAÚNA, S.M., ARRUDA, E.P., ARRUDA, D.E.O. Políticas Públicas em educação a distância: aspectos históricos e perspectivas no Brasil. Pesquiseduca, v.4, n.08, p. 279-295, 2012

BARRETO JUNIOR, Irineu Francisco. Atualidade do conceito Sociedade da Informação para a pesquisa jurídica. In: PAESANI, Liliana Minardi (Coord.). O Direito na Sociedade da Informação. São Paulo: Atlas, 2007.

BARRETO JUNIOR, Irineu Francisco. Proteção da Privacidade e de Dados Pessoais na Internet: O Marco Civil da rede examinado com fundamento nas teorias de Zygmunt Bauman e Manuel Castells. In: DE LUCCA, Newton; SIMÃO FILHO, Adalberto; DE LIMA; Cintia Rosa Pereira. (Org.). Direito \& Internet III. São Paulo: Quartier Latin, 2015. p. 100-127.

BELLONI, Maria Luiza. Educação a Distância. Campinas, SP: Autores Associados, 1999.

BRUNO, Adriana Rocha; LEMGRUBER, Márcio Silveira. Dialética professor-tutor na educação on-line: o curso de Pedagogia-UAB-UFJF em perspectiva. In: III Encontro Nacional sobre Hipertexto. Belo Horizonte, 29 - 31 out. 2009. Disponível em: http://www.ufpe.br/ nehte/hipertexto2009/anais/a/a-dialetica-professor-tutor.pdf. Acesso em: 6 jul. 2018.

CARLINI, Alda. 20\% a distância: e agora? Orientaçóes práticas para o uso de tecnologia de Educação a Distância. São Paulo: Pearson Education do Brasil, 2010.

CASTELLS, Manuel. A Era da Informação: economia, sociedade e cultura. 5 ed. Sáo Paulo: Paz e Terra, 2001. v I, a sociedade em rede.

CAVALCANTI; Ana Elizabeth Lapa Wanderley; LEITE, Beatriz Salles Ferreira; BARRETO JUNIOR, Irineu Francisco. Sistemas de Responsabilidade Civil dos provedores de aplicações da internet por ato de terceiros: Brasil, União Europeia e Estados Unidos da América. Revista Eletrônica do Curso de Direito da UFSM, v. 13, n. 2 / 2018 p.506-531. 
CORTELAZZO, Iolanda. Ambientes de Aprendizagem Otimizados Pela Tecnologia

Educacional. Disponível em: <www.inf.ufes.br/ cvnascimento/artigos/labticendipe.doc>. Acesso em: 24 de set. 2015.

CUNHA, Antônio Geraldo da. Dicionário etimológico Nova Fronteira da Língua Portuguesa. 2. ed. Rio de Janeiro: Nova Fronteira, 1986.

FREIRE, Paulo. Pedagogia da autonomia: saberes necessários à prática educativa. $30 . \mathrm{ed}$. São Paulo: Paz e Terra, 1996.

GROSSI, Ester Pilar; BORDIN, J. (Orgs.) Paixão de Aprender. Petrópolis: Vozes, 1992.

GUAREZI, Rita de Cássia; MATOS, Márcia Maria de. Educaçáo a Distância em segredos. Curitiba: Ibpex, 2009.

LITWIN, Edith (Org). Educação a Distância: Temas para Debate de uma Nova Agenda Educativa. Porto Alegre, Artmed, 2001.

LOBO NETO, Francisco Silveira. Educação a Distância - regulamentaçáo. Brasília: Plano, 2000

MAIA, Carmem. Guia Brasileiro de Educação a Distância. São Paulo: Esfera, 2002.

MAIA, Carmem; Mattar, João. ABC da EaD: a Educaçáo a Distância hoje. São Paulo: Person Prentice Hall, 2007.

MASETTO, Marcos Tarciso (Org.) Docência na universidade. 9. ed. Campinas: Papirus, 2008.

MATTAR, João. Tutoria e Interaçáo em Educaçáo a Distância. São Paulo: Cengage Learning, 2012.

NEDER, Maria Lúcia Cavalli. Licenciatura em educação básica a distância: projeto expansão NEAD/UFMT. In: PRETI, Oreste (Org.). Educação a Distância construindo significado. Brasília: Editora Plano, 2000.

NÓVOA, António O passado e o presente dos professores. In: NÓVOA, A. (Org.) Profissáo Professor. 2. ed. Porto: Porto Editora, 1999.

NUNES, Ivone Barros. A história da EAD no Mundo. In: LITTO, Fredric Michael; FORMIGA, Marcos (Orgs.) Introduçáo à EaD. São Paulo: Pearson Education no Brasil, 2009.

PEREIRA, Jovanira Lázaro. O Cotidiano da Tutoria. In: CORREA, Juliane (Org.). Educação a Distância: Orientaçóes Metodológicas. Porto Alegre: Artmed, 2007.

PETERS, Otto. A Educação a Distância em transição. Leila Ferreira de Souza Mendes (Trad.). São Leopoldo, RS: Editora Unisinos, 2004. 
PRETI, Oreste. Educação a Distância: construindo significados. Brasília: Plano, 2000.

SÁ, Iranita Maria Almeida de. Educação a Distância: processo contínuo de inclusão social. Fortaleza: C.E.C., 1998.

SANTOS, A. O.; OLIVEIRA, G. S. de; JUNQUEIRA, A. M. R. A tutoria em educação a distância: um estudo de caso sobre a função dos tutores a distância. Cadernos da Fucamp, v.15, n. 24, p.19-38, 2016.

THOMPSON, John Brookshire. A mídia e a modernidade: uma teoria social da mídia. 4 ed. São Paulo: Vozes, 1998.

TOMIAZZI, E.; BRITO, M. C. P. O perfil do tutor on-line: competências, atribuiçôes e metas. Colloquium Humanarum, v. 11, n. Especial, p. 1022-1030, 2014.

TONNETTI, F. A. Tutor é professor: algumas consideraçóes sobre o trabalho docente na educação a distância. In: ENCONTRO DE PESQUISADORES A DISTÂNCIA - (SIEDENPED 2012), 1. 2012, São Carlos. Anais...São Carlos: UFSCAR, 2012.

VIGNERON, Jaques. Comunicação Interpessoal e formação permanente. São Paulo: Angellara, 1997. 